\title{
Use of an Emergency Medical Pictorial Communication Book During Simulated Disaster Conditions-ERRATUM
}

\author{
S. Behar, R. Benson II, A. Kurzweil, C. Azen, and A.L. Nager
}

doi:10.1017/dmp.2013.86, Published by Cambridge University Press, 20 August, 2013.

$\mathrm{I}$ $\mathrm{n}$ "Use of an Emergency Medical Pictorial Communication Book During Simulated Disaster Conditions" (originally published online August 20, 2013) an error regarding "Figure 2 - Percent Rates of Question Responses Marked 'Unable to Obtain Information"' appeared. The legend variables corresponded incorrectly to the chart. 'MEC book' correctly should correspond with the darker colour;
'No MEC book' should correspond with the lighter colour. The author regrets this error.

\section{REFERENCE}

Behar S, Benson R II, Kurzweil A, Azen C, Nager AL. Use of an Emergency Medical Pictorial Communication Book During Simulated Disaster Conditions. Disaster Medicine and Public Health Preparedness. 2013;7. doi:10.1017/dmp.2013.86. 